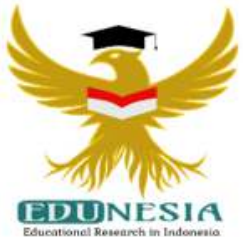

\title{
The Analysis of Pedagogical Competence of The English Teachers' of The Third Grade Students at SMA Negeri 3 Banda Aceh
}

\author{
Rosdiana \\ Pendidikan Bahasa Inggris, STKIP Bina Bangsa Getsempena, Indonesia \\ Corresponding Email: rosectz15@gmail.com, Phone Number : 0853-xxxx-xxxx
}

\author{
Article History: \\ Received: Juni 11, 2020 \\ Revised: Juni 17, 2020 \\ Accepted: Juni 22, 2020 \\ Published: Juni 24, 2020
}

Keywords:

Teacher Pedagogical

Competence.

Kata Kunci:

Kompetensi Pedagogik

Guru.

How to cite:

Rosdiana. (2020). The analysis of pedagogical competence of the English teachers' of the third grade students at SMA Negeri 3 Banda Aceh. Edunesia : Jurnal Ilmiah Pendidikan, 1 (2): 1-5

This is an open access article under the $C C-B Y-N C-N D$ license (c) (1) $\$$

\begin{abstract}
This research tries to analyze the teacher's pedagogical competence in Teaching English. There are six pedagogical competence that need to be mastered by a teacher. They are understanding the subject in English lesson, the ability in understanding the students, the ability in setting and implementing lesson plan and learning strategy, the ability in creating educational and dialogical learning which is interactive, utilizing the learning technology, and evaluating the learning outcomes. Thus, this research focus on the teacher's pedagogical competence that consist of the six components. This research uses a descriptive qualitative approach and the researcher used observation, questionnaire, and document analysis as the method of collecting data. The objective of this research is to know whether the English teacher has all components in pedagogical competence and to know the students' perpective on the teacher's pedagogical competence. The result of research is the English teacher has all of the components of the pedagogical competence. Based on the observation, documentation analysis, and the data of questinnaire shows that the English teacher has the abilty in understanding the subject in English lesson, the ability in understanding the students, the ability in setting and implementing lesson plan and learning strategy, the ability in creating educational and dialogical learning which is interactive, utilizing the learning technology, and evaluating the learning outcomes.
\end{abstract}

Abstrak: Penelitian ini mencoba menganalisis kompetensi pedagogik guru dalam Pengajaran Bahasa Inggris. Ada enam kompetensi pedagogik yang perlu dikuasai oleh seorang guru. Mereka memahami subjek dalam pelajaran bahasa Inggris, kemampuan dalam memahami siswa, kemampuan dalam menetapkan dan menerapkan rencana pelajaran dan strategi pembelajaran, kemampuan dalam menciptakan pembelajaran pendidikan dan dialogis yang interaktif, memanfaatkan teknologi pembelajaran, dan mengevaluasi hasil pembelajaran . Dengan demikian, penelitian ini fokus pada kompetensi pedagogik guru yang terdiri dari enam komponen. Penelitian ini menggunakan pendekatan kualitatif deskriptif dan peneliti menggunakan observasi, kuesioner, dan analisis dokumen sebagai metode pengumpulan data. Tujuan dari penelitian ini adalah untuk mengetahui apakah guru bahasa Inggris memiliki semua komponen dalam kompetensi pedagogis dan untuk mengetahui perspektif siswa tentang kompetensi pedagogis guru. Hasil penelitian adalah guru bahasa Inggris memiliki semua komponen kompetensi pedagogis. Berdasarkan pengamatan, analisis dokumentasi, dan data kuesioner menunjukkan bahwa guru bahasa Inggris memiliki kemampuan dalam memahami subjek dalam pelajaran bahasa Inggris, kemampuan dalam memahami siswa, kemampuan dalam menetapkan dan menerapkan rencana pelajaran dan strategi pembelajaran, kemampuan dalam menciptakan pembelajaran pendidikan dan dialogis yang interaktif, memanfaatkan teknologi pembelajaran, dan mengevaluasi hasil pembelajaran. 


\section{A. Introduction}

Education is an activity that has purpose and it can guide people toward the purpose they want to achieve (Hasbullah, 2005). Further, with education a person can develop their ability in terms of mentality, physical and their mindset in order to be better in the society"s life

The institution of education have an important role in education field since it is one of the effort to increase the quality of education. Indirectly, the education can be obtained whether from the book or society when we have an interaction with them. School is the most effective institute to obtain knowledge for students. It is one of education institution which has some goals, such as achieving education target, implementing the education in the form of teaching; including teaching English.

Meanwhile, English is a tool to express idea, thought, argument, and feeling orally or written. In indonesia, English lesson is not only purposes to make students smart in English but also as a tool to reserve and develop knowledge, technology, and art-culture. However, English language is one of a lesson which is hard to be understood by the student as general. It is because the limitation of students" understanding with the subject that is learned. There are some factors that made the students" understanding is limited. The most prominent factor is the teachers" pedagogical competences who teach English.

Mostly, it is believed that teachers actually have in-depth knowledge and skills in a particular field of science. However, the knowledge and skills are not enough to make them able to teach well, they also need to have teaching skills or pedagogical competence (Hotaman, 2010). Moreover, Indonesian Government Regulation No. 74, 2008 on Teachers and lecturers defines that teacher"s pedagogical competence is the ability of teacher in learning management of the learners. There are six components of pedagogical competence that must be possessed by a teacher; understanding the subject in English lesson, understanding the students, having the ability in setting and implementing lesson plans and learning strategies, having the ability in creating educational and dialogical learning which is interractive, utilizing of learning technology, and evaluating learning outcomes.

Based on the researcher"s observation at SMA Negeri 3 Banda Aceh, it is found that the school has good teaching and learning in English language lesson. It can be seen from the student"s achievement in studying English. A good teacher is the most determinant of the students" achievement in the classroom (Hayes, 2003). A teacher is considered as a successful teacher in teaching the subject toward the student if the student understands about the subject that is taught by the teacher.

Thus, the achievement of the students is seen from how the teachers master all the abilities of teaching. In this case, the researcher observes that the student understand the subject that is taught by the teacher easily, also the student are active while teaching and learning process. Furthermore, as a proof that students understand the subject, when the teacher gives some exercises unexpectedly, the students are able to answer the question correctly. Furthermore, the students were also active in asking and answering questions both from the teacher. In the section of discussion, the students were also able to conclude the materials taught during the teaching and learning process. It means that teacher's pedagogy competence could improve students' motivation to learn.

This research, therefore, is going to analyze the teacher"s pedagogical competence in teaching English for the Second Grade of Senior High School, particularly in SMA 3 Banda Aceh. SMA Negeri 3 Banda Aceh is implementing the curriculum of 2013. The demands of the 2013 curriculum require an educational process that provides opportunities for students 
to develop all their potential. Potential related to aspects of attitude (affective), knowledge (cognitive), and skills (psychomotor). These aspects are developed so that they can be meaningful in life in a community, nation, for the welfare of human life. In addition, the other evidence is the student achievement in English lesson. The student obtain high score and above KKM. The KKM in the school is 75, and the average of the student"s score is 80 . Therefore, the researcher assumes that teaching and learning process that handle by the teacher is successful that is proven by the fact that the students score in English is high. The teaching and learning achievement is not regardless of the teacher"s ability on how the teacher manages the class. The ability to manage the class is a part of pedagogical competence. Therefore, the researcher wants to obtain the valid data by conducting a research about English teacher's competence.

\section{B. Method}

This research use descriptive method which aims to provide a systematic and careful with the actual facts and nature of certain populations which aims to solve the current problems and collect data or information to be arranged, described, and analyzed. In this research, the writer uses the observation, questionnaire and documentation in collecting the data.

Furthermore, in the technique of analysis the writer does the following steps to collect the data. Firstly, the researcher observed an English teacher while teaching English in the classroom and take some note on how the teacher teach the students. Secondly, the researcher give the questionnaire to the student as respondents to obtain the data, this questionnaire contains some statements in measuring the ability of pedagogical competence of the teacher.

Thirdly, the researcher take documentation in the form video while teaching and learning activity, lesson plan, and the student's result in learning English. The documentations are analized by the researcher to know how the teacher ability in implementing the lesson plan, furthermore the researcher also intended to know the teacher activity while teaching and learning activity, and the last the researcher will analize the student"s result in order to know the teacher and students achievement in English lesson.

\section{Result and Discussion}

The finding of the research that has been discovered for the six aspects of pedagogical competence. They are: understanding the subject in English lesson, understanding the students, having ability in setting and implementing lesson plan and learning strategy, having ability in creating educational learning, utilizing technology as media in learning activity, and evaluating learning outcomes.

Understanding the subject in English lesson means a teacher, $\mathrm{s}$ ability in understanding the learning material to be taught. Based on the researcher"s observation in the class of XI MIPA 6, the English teacher was able to master the subject in English lesson. It can be seen from how the teacher explained the subject toward the students. She explained the subject apparently so that the students understand about the material being taught. As the proof that the students understand the learning material, when the teacher gave them some questions about the subject being taught, they were able to answer it. Furthermore, the other evidence that the teacher understand the subject in English lesson 
is the English teacher was able to answer all students" question while teaching and learning activity.

The researcher also found that the English teacher was able to set and design the lesson plan. The teacher matched the lesson plan with the students" activity that appropiate with the subject matter being taught. Furthermore, the teacher implemented the learning process that appropiate with the lesson plan that have been designed. For instance, in the lesson plan there are teacher and students" activity such as observing, enquiring, collecting information, processing information, and communicating the information.

The English teacher motivated the students to be active in learning. It can be seen from how the teacher is able to support the students to learn. The teacher tell about some people who are success and fail in their life to motivate the students. In addition, the teacher is not only use speech method, but also question and answer method, discussion, and group discussion. The varian of methods is able to make the students are not borried in learning while teaching and learning process.

Furthermore, based on lesson plan analysis, the english teacher implemented the strategy of pendekatan ilmiah (scientific approach) that it supported by: guided observation, open-ended question, Think Pair Share (TPS), anecdotal record, brainstorming, mind mapping, inquiry, experiment, and teamwork. The varian of strategies will make the students are interested to study and make the students are not bored in studying the subject being taught. Based on the explanation above, the researcher conclude that the English teacher has the ability in setting and implementing lesson plan and learning strategies. Based on the research finding of observation, questionnaire, and documentation, the English teacher is able to master the subject in English lesson. It can be seen from how the teacher can explain the subject toward the students clearly. Furthermore, the other evidence is the English teacher is able to answer all students" question while teaching and learning activity. In addition, the English teacher also tried to associate the English subject with the other relevant knowledge, and the students real life. For example, the English teacher often ask the students to perform dialogue about the subject that is taught based on the students experiences. Therefore, It makes the students easy to understand the subject which is taught by the teacher.

Furthermore, based on the students" perception that is got from questionnaire, most of students are agree that the teacher understand the Emglish subject in English lesson. There are two questions for understanding the subject in English lesson of the questionnaire. The researcher ask whether the English teacher master all the subject in English lesson while teaching and learning activity and the second question is whether the English teacher implement learning theory while teaching and learning activity.

In addition, the English teacher took the learning materials from many source, such as books (Pathway to English and Stop Bullying Now) which are the most popular book and used by a lot of teacher in senior high shool. The English teacher also took the other source is internet site from youtube, google, e.t.c. to ensure that the teacher really understand about the subject matter being taught. Those sources will be the prove that the teacher understand the subject matter since the teacher is not only took the material from book, but also from the other source to make the teacher understand about the subject matter. 
Based on the result of data that is taken from observation, questionnaire, and documentation, the researcher conclude that the English teacher has the ability in understanding the subject in English lesson.

\section{Conclusion}

The researcher conclude that the English teacher of MIPA 6 class have a good pedagogical competence in teaching English. It was found in the research finding of observation, questionnaire, and documentation. The data shows that the English teacher has all aspects in pedagogical competence. There are six aspects of pedagigical competence. They are understanding the subject in English lesson, understanding the students, having the ability in setting and implementing lesson plans and learning strategies, having the ability in creating educational and dialogical learning which is interactive, utilizing the learning technology, and evaluating the learning outcomes.

\section{References}

Ada, Z.H. (2016). The contribution of teachers' pedagogical competence toward the effectiveness of teaching of English at MTsN balang - balang. Universitas Islam Negeri Alauddin Makassar.

Best, J.W., \& James. (2006). Research in Education 10th Edition. Boston: Pearson Education.

Deborah, R. (2009). An Introduction to Triangulation. UNAIDS Monitoring and Evaluation Division : UNAIDS

Hamidi. (2004). Metode Penelitian Kualitatif: Aplikasi Praktis Pembuatan

Hayes, D. (2003). Inspiring Primary Teaching. London: British Journal of Education

Loughran, J. (2010). Developing a Pedagogy of Teacher Education. London: Routledge

Mazumder, B. (2008). Teachers Educatioanal Assessment.Dhaka Nursing College: Dhaka. Proposal dan Laporan Penelitian. Malang: UMM Press.

Qodriyah, W.R. (2016). An Analysis of teachers' pedagogical competence in teaching English for young learners at NARA Islamic school Cirebon. Syekh Nurjati State Islamic Institute Cirebon.

Sugiyono, A. (2011). Pengantar Statistik Pendidikan. Publisher: Raja Grafindo Persada. Jakarta.

Syahrul, M. (2016). The Analysis of Pedagogical Competence of The English Teachers' of The Second Grade Students at MTs Negeri 1 Jeneponto in Teaching English. Universitas Islam Negeri Alauddin Makassar in 2016. 